\title{
Teonomías. Figuras de derecho en la antigua Grecia
}

\section{Theonomies. Figures of Law in the Ancient Greek}

\author{
Gabriel ARANZUEQUE \\ Universidad Autónoma de Madrid
}

Recibido:10/10/2010

Aceptado: 25/01/2011

Nómos d'archaîos áristos.

Hesíodo, fr. 322.

\section{Resumen}

De Homero a Heráclito, este trabajo estudia las distintas caracterizaciones de la ley divina en la Grecia arcaica. Analiza la sustitución metonímica de la divinidad como fuente de derecho por el nómos ciudadano, y muestra la violencia simbólica y el olvido activo asociados a ese proceso de fundación política a partir del siglo V. Por último, reconstruye la axiología del marco oral de las antiguas teonomías e incide en el papel desempeñado por la escritura en la refiguración de la esfera jurídica griega durante el período clásico.

Palabras clave: ley, justicia, derecho, oralidad, lectura, escritura, Grecia.

\begin{abstract}
This work studies the different characterizations of the divine law in the Ancient Greek from Homer to Heraclitus. It analyzes the metonymic substitution of the divinity as the source for the law by the citizen's nómos, and shows the symbolic
\end{abstract}


violence and the active oblivion associated to this process of political foundation from the $5^{\text {th }}$ century. Finally it rebuilds the oral frame's axiology of the old theonomies and emphasizes the role of writing in the refiguration of the Greek juridical field during the classic period.

Keywords: law, justice, right, orality, reading, writing, Greece.

Uno de los caballos de batalla de la reflexión jurídica ha sido siempre la diacronía del cuerpo legal. Pese a establecerse con vistas a su perdurabilidad, el conjunto de normas que regula las relaciones cívicas no puede hacer caso omiso de su carácter circunstancial, ni es ajeno a su naturaleza discursiva. Todo mecanismo de legitimación precisa el refrendo del tiempo. Al fechar un decreto, al abrogar una sentencia pasada o al promulgar el marco posible de la acción por venir, se signa la transitoriedad de lo escrito, su obligado desuso. De ahí que suela plantearse, ante el texto de la ley, el siguiente problema: ¿cómo conjugar el prurito de perennidad que anima la praxis legislativa con su irrevocable obsolescencia?, ¿cómo conciliar la perentoriedad del dictamen público con su inevitable supresión? Como vamos a ver en lo que sigue, Grecia no ignoró esa ambivalencia del marco legal, escindido entre la necesidad de su akinesía y su forzosa extracción o eliminación (exaíresis); pero trató de potenciar simbólicamente su aspecto recurrente, haciendo caso omiso de un fenómeno incontrovertible: entre la inscripción de los nómoi y su borradura (aphaíresis), mediaba el paso del tiempo destructor (chrónos), el desgaste que prohibía la eternidad (aei) de lo fijado.

A mediados del siglo $\mathrm{V}$, resulta notorio al respecto que uno de los operadores primordiales del imaginario político-religioso fuese el simulacro de la escritura legislativa. Al romper con su propia arché, con el poder constrictivo de origen sagrado que emanara antaño de la voluntad divina, así como con la violencia implícita en las propuestas del tribunal popular, el nómos se convirtió en una de las figuras retóricas del sistema de representaciones helénico. Aun a despecho de negar el combate larvado que segmentaba la pólis (la diaphorá que presuponía toda symploké efectiva), la institucionalización de la justicia transformó el theîos nómos arcaico en el punto de encuentro ideológico que salvaguardaba la homónoia ciudadana. De ese modo, se pretendió domeñar katà nómon la irrupción performativa del palaiòs lógos de la divinidad, al mudar su fuerza intempestiva en el lazo inmóvil (akinetos) de la koinonía. Ahora bien, al igual que las kýrbeis del Pritaneo giraban es méson una y otra vez mostrando los distintos pasajes legales del sedicente estatismo del dêmos, la lectura de la ley, su historía, también se escandía en múltiples figuras. 
Nos gustaría mostrar a continuación el contexto tropológico que acompañó a la juridificación de lo sacro a partir del siglo VIII, así como los procesos de sublimación mediante los que dicha reglamentación se personificó en la figura del poder soberano, fue ensalzada y enaltecida. Para ello, quisiéramos comenzar con el claro contraste existente entre el modo en que Platón idealizó la antigua justicia teonómica y la emulsión definitiva de la thémis sacra arcaica que llevó a cabo la Atenas democrática.

\section{I}

En la época de Cronos, comenta Platón en las Leyes (713 b y ss.), los dioses asistían al género humano con plena justicia y autoridad. Ejercían un poder omnímodo (despótes) que les permitía reglamentar con espontaneidad (automatía) y plenos poderes (autokráteia) los movimientos de su grey. La reflexividad de tò autó generaba por sí sola la eunomía. No había familias ni ciudades, ni ningún otro vínculo más allá del sometimiento a los dictados de la divinidad. La tierra se bastaba para suministrar lo necesario para la subsistencia, de su seno brotaban los rebaños de hombres y todos se solazaban en el regazo de eudaimonía ${ }^{1}$. Bajo la férula no sólo del más fuerte (kreitton) sino del mejor (ameínon) linaje, cada parte (méros) satisfacía sus necesidades y nadie conocía la pesadumbre de la éris ${ }^{2}$. La autoproducción del génos de la divinidad se confundía con la distribución (nómos) equitativa del kósmos, esto es, la repetición cabal del mismo patrón jurídico frustraba la proliferación de todo posible disenso. De hecho, la identidad iterativa de la ley y su carácter divino eran intercambiables.

Platón, empero, era perfectamente consciente de que el período transcurrido desde el tiempo de Cronos resultaba insoportable e inconcebible (átletos kaì amé(chanos) $)^{3}$. Entre el pasado originario del theòs nómos y el convulso presente de la

\footnotetext{
${ }^{1} \mathrm{Al}$ cifrar la felicidad humana en la próvida espontaneidad de la naturaleza, Platón recupera la rentabilidad ideológica del mito del Político (268 d-277 a), donde el hecho de ser oriundo (autóchthon) parece suponer una de las condiciones necesarias de la andreía. Para el griego, sólo el nacido de la tierra (ek tês gês) puede hacer gala de una ilustre cuna (eugenía). Cf. Político, 269 b; Menéxeno, $237 \mathrm{~d}-$ 238 a; Himno homérico a la tierra madre de todos, 11. Vid. Vidal-Naquet, P: «Plato's Myth of the Statesman», en Journal of Hellenic Studies, no 98, 1978, pp. 132-141.

2 Platón: Político, 271 e. Para Platón, sólo la acción divina sirve de salvaguarda al kósmos ante la conminación del tópos infinito de la desemejanza ( 273 d-e). Es decir, sólo el ser idéntico a sí mismo, que siempre se comporta del mismo modo ( $269 \mathrm{~d})$, puede servir de baluarte inflexible frente las embestidas del pólemos. Como vamos a ver, el nómos cumple una función equipolente, a saber, evitar la descomposición (diálysis) de la ciudad.

3 Platón: Leyes, 676 b. Cf. Político, 269 b: «Todas estas historias -observa el Extranjero, antes de pasar a narrar el mito sobre la reversión periódica del universo- tienen su origen en un mismo acontecimiento (páthos) y, además de éstas, muchísimas otras aún más maravillosas (thaumastà). Pero en razón del
} 
pólis, se abría una sima insondable, ho chrónos, que sólo la escritura podía colmar. Al menos eso es lo que se desprende del comienzo del Timeo, donde los grámmata se presentan como uno de los medios imprescindibles para la regimentación de la ciudadanía (23 a). En calidad de mnêma, el signo escrito preserva las directrices de las formas de gobierno pretéritas y posibilita el recuerdo de su capacidad legislativa (nomothesía $)^{4}$. Por ello, la escritura, de haber existido con anterioridad, podría haber colmado el vacío que separa las directivas presentes de su arché, es decir, del antiguo código helénico (palaiòs kaì ellenikòs nómos) que Platón idealiza en las Leyes $^{5}$. A nuestro juicio, dicha legislación refiere al nómos acorde con la naturaleza (katà phýsin) del Timeo (24 b-c), donde se pone de manifiesto la relación paternofilial entablada entre las normas humanas y las divinas: «También ves -comenta Critias a Sócrates- cuánto se preocupó nuestra ley (nómos) desde sus inicios por la sabiduría, pues, tras descubrirlo todo acerca del universo, incluidas la adivinación (mantiké) y la medicina (iatriké), lo trasladó de estos seres divinos al ámbito humano, para salud (hygíeia) de éste, y adquirió el resto de los conocimientos (mathémata) que están relacionados con ellos». Como puede apreciarse, el marco jurídico se presenta kat'archás como una transposición o extensión (aneúrysis) de la phrónesis divina, como una adquisición salutífera de conocimiento mántico. Esa proximidad de la antigua legislación a las prácticas adivinatorias confirma el vínculo estructural que concatena chresmós, nómos y hygíeia en el ideario griego6; pero pone de relieve, asimismo, la distancia infranqueable que escinde la normativa vigente de la presunta eunomía de los ancestros, producida y alentada directamente por la divinidad. Al indicar el posible nexo, Platón subraya necesariamente la disyunción, la diferencia temporal, jerárquica y cualitativa que departe ambos dominios; en suma, la heterogeneidad que tratará de subvertir la escritura al autoproclamarse instancia de legitimación de la prâxis pública.

Resulta irónico que Platón denomine a los hombres ágrafos (agrámmatoi) del pasado «ámousoi» («incultos», «sin gusto», «ajenos a las Musas») 7 , cuando, de

larguísimo tiempo (plêthos chrónou) transcurrido, algunas de ellas han acabado por perderse y otras, que se han ido dispersando, se narran por separado, desconectadas entre sí».

4 A propósito de la relación entre mnéme y politeía, véase Platón: Leyes, 678 a. Aristóteles también destaca la importancia del escrito histórico en orden a las deliberaciones públicas, mostrando su utilidad a la hora de conocer las formas de gobierno del pasado más ventajosas para la comunidad política: Retórica, I, 4, 1360 a 35-38; Política, VI, 1319 b 33-1320 a 4.

5 Ibid., 659 b. Respecto a las leyes ancestrales de la antigua Grecia, véase de Romilly, J: L'idée de loi dans la pensée grecque des origines à Aristote, Paris, 1971, pp. 40 y ss.

${ }^{6} \mathrm{Al}$ respecto, véase nuestro artículo: Aranzueque, G.: «Políticas de la revelación. Lógos y krátos en la tradición oracular griega», en Pensamiento, vol. 55, n 213, 1999, pp. 413-440.

7 Platón: Timeo, 23 a-b. Cf. Eurípides, Ion, 526; Platón: República, 411 d; Critias, 109 d-e. Sobre el uso que hace Platón del término «ámousos» en relación con la escritura, véase Brisson, L.: Platon, les mots et les mythes. Comment et pourquoi Platon nomma le mythe?, Paris, 1994, pp. 45 y ss.; Detienne, M.: L'invention de la mythologie, Paris, 1981, pp. 164 y ss. Trad. cast.: La invención de la mitología, 
hecho, como es sabido, si algo definía la comunicación oral en los tiempos previos al desarrollo de la escritura era el culto de la voz y el carácter profético de la memoria, asociados respectivamente a Kalliópe y Mnemosýne. Como se verá a continuación, el discurso platónico se desenvuelve en un marco inconmensurable respecto a los valores religiosos de la cultura oral arcaica, y parece haber olvidado, efectivamente, muchos de los usos y costumbres precedentes. Aunque en ningún momento cae en la tentación de convertir la escritura en el único modo de suscitar el recuerdo (mnémen poieîn), como ejemplifica a ojos vistas el mito de Theuth en el Fedro, participa de la opinión de que la civilización política no puede darse sin las bondades del nómos escrito. A decir verdad, se encuentra entre la añoranza del derecho natural ordenado por la divinidad y la necesidad de establecer una legislación escrita que redima al género humano de su naturaleza salvaje (agriótes) $^{8}$. Por ello, si bien su objeto consiste en encauzar la anthropeía phýsis mediante una norma autónoma, la presencia del nómos pánton basileús pindárico se deja sentir a lo largo y ancho de todo su proyecto político 9 . A todas luces, el fin perseguido por la actividad jurídica es plenamente humano (reformar el entendimiento, interiorizar la ley escrita como dianomè tô̂ nô, como norma reguladura de la mente); pero el métron de la misma recae en la divinidad, al menos nominalmente ${ }^{10}$.

A nuestro modo de ver, Platón trata de conciliar lo inconciliable una vez que, en la segunda mitad del siglo $\mathrm{V}$, se ha producido la distinción entre nómos y phýsis. El carácter universal del antiguo nómos basileús es irrecuperable desde el momento en que su potencialidad demiúrgica sólo acontece hos phánai, como basamento de la naturaleza, y no como agente implicado de forma efectiva en los asuntos humanos,

Barcelona, 1985, pp. 111 y ss. Para Platón, la cultura ágrafa sólo conoce algunas genealogías, esto es, sucesiones de onómata sin un nexo narrativo depurado o riguroso. $C f$. Detienne, M.: L'écriture d'Orphée, Paris, 1989, pp. 176 y ss. Trad. cast.: La escritura de Orfeo, Barcelona, 1990, pp. 144 y ss. 8 Platón: Leyes, 874 e-875 a. Cf. Protágoras, 327 d, donde los nómoi, la actuación de los tribunales (dikastéria) y el acicate de anánke se suman a la paideía para lograr de consuno la práctica de la areté. Obsérvese que, a juicio de Platón, el hombre más injusto de la pólis atesoraría más virtudes que el mejor de los salvajes.

9 Véase, por ejemplo, Leyes, 690 y ss. Pese a todo, ha de subrayarse que, inversamente a Píndaro, Platón no acepta la imposición violenta de la ley divina, la justicia de sus érga bíaia. Frente al krátos arcaico del theîos nómos, el Ateniense de las Leyes hace valer la necesidad de contar con el beneplácito de la voluntad humana; a saber: la archè toû nómou sólo podrá ser katà phýsin si se admite hekóntos. Ahora bien, ¿qué tipo de religiosidad puede condicionar la capacidad de actuación de lo divino? ¿No se ha producido un vuelco en el modo de relacionarse con los dioses, al transformar el antiguo régimen de la epipháneia en una política legitimadora en la que tò theîon sólo desempeña el papel de garante subsidiario, cuando no de convidado de piedra? El límite de esa ruptura con el esquema de poder arcaico puede encontrarse en la Política de Aristóteles (III, 1287 a), donde se llega a adoptar un patrón estrictamente opuesto, al defender que la pambasileía no puede ser katà phýsin.

10 Platón: Leyes, 714 a. Cf. 716 c: «Para nosotros, la divinidad ha de ser la medida de todas las cosas, en grado sumo y mucho más que, como suele decirse, el hombre (ho dè theòs hemîn pánton chremáton métron àn eie málista, kaì poly mâllon é poú tis, hós phasin, ánthropos)». 
tal como sucede en los relatos míticos. De la personificación de la divinidad que opera el mundo homérico se ha pasado a un garante abstracto que se limita a apuntalar en la distancia el señorío de la constitución ciudadana. Es más, se lleva a cabo tal desplazamiento en su capacidad operativa que, en la práctica, resulta prescindible. De ahora en adelante, la arché pertenecerá, no al nómos tês phýseos, sino al nómos despótes tôn archónton, a los servidores (hyperétas) de las leyes del dêmos ${ }^{11}$. Ellos serán los encargados de someter los abusos de la violencia a la acción de la justicia (dikaieûn tò biaiótaton).

Ahora bien, ¿qué fuerza ejerce esa suplantación?, ¿cuál es la estrategia de poder en juego?, ¿no violenta el krátos del dêmos, simbolizado por la estela de la ley, la antigua dike del nómos týrannos tôn anthrópon?, ¿por qué ocultar esa bía?, ¿acaso por resultar demasiado evidente su hýbris? Lo cierto es que no parece factible el hecho de servir a las leyes y el pretender seguir siendo hyperétes tôi theôi, como pretenden Platón y Aristóteles ${ }^{12}$, a no ser que por «theós» se entienda algo muy distinto al nómos basileús arcaico, o, lo que es lo mismo, a no ser que el paso del tiempo, debido a la falta de escritura, entrañe el olvido de la especificidad del nómos ágraphos. De ahí a erigir la ley escrita (nómos graptós) en máximo exponente del poder democrático sólo hay un paso. El problema es que ese avance táctico era la expresión preclara del biaiôn tò dikaiótaton que la nueva concepción legislativa pretendía suprimir. Lo esencial es que dicha abolición también comportaba un tipo de violencia que fue elidido de forma interesada. ¿Cuál era la lógica de tal exceptuación? ¿No se enfrentaba el nuevo esquema jurídico al rhézein del antiguo nómos díkes, a su violencia antaño calificada de justa y legítima (dikaía)? ¿Por qué se trataba de obviar esa cesura? ¿Cuál era el rédito político-religioso que reportaba su omisión? ¿Cómo se reforzaban entre sí, en la economía del imaginario clásico, el supuesto olvido del palaiòs nómos y la represión del krátos nómou inherente al ejercicio del derecho? ¿Qué papel desempeñó, por ejemplo, la traslación simbólica de las leyes de Solón de la colina sagrada de la Acrópolis al méson del agorá?13. ¿Acaso resultaba indiferente el emplazamiento de los nómoi? No lo creemos. Al perder su posición elevada (káto choreîn), la política del espacio ciudadano sufrió

\footnotetext{
11 Ibid., 715 a-c.

12 Platón: Leyes, 773 e; Aristóteles: Política, III, 1287 a 28-29: «Así pues, el que defiende el gobierno (arché) de la ley (nómos) parece defender el gobierno de la divinidad (theós) y de la inteligencia (noûs)». La relación entre nómos y noûs ya había sido desarrollada por Platón en distintos pasajes de las Leyes: 644 d-645 a; 674 b; 713 e-714 a. Lo mismo sucede con la naturaleza divina de la inteligencia: Platón: República, 590 c-591 c. Cf. Aristóteles: Ética a Nicómaco, X, 7, 1177 b 26 y ss.; Píndaro: Nemeas, VI, 5.

13 Cf. Stroud, R. S.: The Axones and Kyrbeis of Drakon and Solon, Berkeley/Los Angeles, 1979, pp. 12-13; Bérard, C.: «L'héroïsation et la formation de la cité: un conflit idéologique», en Architecture et société. De l'archaïsme grec à la fin de la république romaine, Roma-Paris, 1983, pp. 43-59; Loraux, N.: La cité divisée, Paris, 1997, pp. 68-72.
} 
una conmutación sin precedentes y proyectó en la ley escrita toda la fuerza de la acción pública. El desplazamiento metonímico fue tan acusado que la propia actividad del dêmos pasó a llamarse graphé.

\section{II}

En este artículo, quisiéramos hacer hincapié en la violencia ínsita en el nómos hýbreos, en la hýbris acallada de un gráphein que, en un principio, no significó «trazar», «escribir» o «pintar», ni «acusar» o «dictar sentencia», sino «arañar», «cortar» o «desollar» 14 . Por de pronto, nos limitaremos a bosquejar algunos de los aspectos más relevantes del nómos ischyrós que regía espontáneamente la totalidad de la phýsis en el mundo arcaico. Sin prejuzgar el carácter panhelénico de dicha descripción, quisiéramos apuntar algunos de los rasgos característicos que motivaron que el nómos ágraphos figurase, para el griego, al cabo del tiempo, entre los elementos conspicuos de tà koiná. «Común (koinós) -comenta Aristóteles-es la ley conforme a la naturaleza (katà phýsin), pues existe ciertamente algo, que todos adivinan, comúnmente considerado como justo (dikaios) o injusto (ádikos) por naturaleza, aunque no exista comunidad ni haya acuerdo (synthéke) entre los hombres» ${ }^{15}$. A pesar de su aparente sintonía con la religiosidad arcaica, lo más sorprendente de la definición aristotélica no es tanto el alcance de su marco ostensivo, cuanto el uso que hace del verbo manteúo. Como puede apreciarse, la revelación de tò physikòn dikaion ha dejado de ser una prerrogativa del grupo estatuido de videntes para pasar a ser una aptitud «común a todos» (epi pâsi koinós). La facultad de difundir el nómos phýseos ya no recae en el thymós del maestro de verdad elegido por Apolo, sino en el noûs divino que comparten háma pántes, todos sin excepción.

Por el contrario, en la Teogonía de Hesíodo, sólo el basileús que recibe de las hijas de Zeus (Diòs koûrai), al igual que el aedo, el don (timé) de la meilíchia, de la dulce oratoria, resulta competente a la hora de examinar, ejecutar, distinguir o interpretar (diakrinein) las thémistes. Es decir, sólo el meilichóphonos honrado por las Musas puede pronunciar rectas sentencias (itheîai dikai) ${ }^{16}$. La voz del rey arcaico detenta una función demiúrgica y judicativa, cuya thésis metajurídica remite siempre a la sabiduría de Zeus. Como se muestra en el mito de Pandora17, la mêtis del

\footnotetext{
14 Homero: Ilíada, IV, 139; VII, 187; XI, 388; XIII, 553; XVII, 599; Odisea, XXII, 280.

15 Aristóteles: Retórica, I, 14, 1373 b 6-9. Cf. Ética a Nicómaco, V, 7, 1134 b 18-1135 a 6. La relación entre koinós y nómos ágraphos se había establecido con anterioridad en la Retórica (I, 10, 1368 b 79): «Llamo particular a la ley escrita por la que se gobierna cada ciudad; y común a las leyes no escritas sobre las que parece haber un acuerdo unánime en todos los pueblos»».

16 Hesíodo: Teogonía, 80-86.

17 Hesíodo: Los trabajos y los días, 104-105. Cf. ibid., 143-144.
} 
Cronión proporciona o niega la phoné a los hombres y, con ella, brinda la posibilidad de la justicia. Las normas son objeto de una distribución (nómos) oral que explica, decide e interpreta (krínei) el derecho natural de la ciudadanía. Su violación se enfrenta al murmullo tumultuoso (rhóthos) suscitado por el Juramento (Hórkos), y su entonación tiene por objeto principal mudar la hýbris del oyente (akoustés) ${ }^{18}$. Los valores acústicos determinan su carácter ajustado, avasallador o irresistible. Sólo el nómos divino promulga tò áriston, la dike digna y respetable entre los dioses (kydrá; lit.: «gloriosa», «ilustre»), esto es, el krátos capaz de doblegar la dike d'en chersí, la fuerza sin pudor (aidós) del hombre violento (cheirodíkes) ${ }^{19}$.

Asimismo, entre la aristocracia homérica, como es sobradamente conocido, la realización de la dike concierne al báculo (skêptron) del koíranos, al caudillo a quien la divinidad ha concedido la facultad de decidir en la boulé lo que ha de hacerse (hó ti chrè poieîn) en cada situación concreta. De nuevo la acción política cifra su necesidad en la obligatoriedad de las thémistes dispensadas por Zeus, y únicamente el basileús resulta capacitado para administrar como es debido (hé thémis estí) los avatares de los aqueos: «No es bueno el caudillaje de muchos; sea uno solo el caudillo, uno solo el rey, a quien ha otorgado el taimado hijo de Cronos el cetro y las leyes, para decidir con ellos en el consejo» ${ }^{20}$. La elocución del ánax, amparada en la infalibilidad de su símbolo de investidura, persevera y cumple su propósito (télos): el bienestar y la opulencia de los mortales. A su vez, la prosperidad generada por las leyes revierte en beneficio del gobernante, al aumentar su dignidad, su honor y su estima (timé). El carácter indefectible de sus preceptos aproxima su papel funcional al del dios ${ }^{21}$, y hace de la enunciación normativa de la thémis una de las expresiones referenciales de su autoridad 22 .

18 Ibid., 213, 220-224. Véanse Havelock, E. A.: The Greek Concept of Justice, Cambridge (Mass.), 1978, p. 216 y n. 16; Svenbro, J.: Phrasikleia. Anthropologie de la lecture en Grèce ancienne, Paris, 1988, p. 128.

19 Ibid., 256-257; 274-280: «Grábate esto en el corazón, escucha la voz de la justicia y olvídate por completo de la violencia, pues esta ley (nómos) impuso a los hombres el Crónión: a los peces, fieras y aves voladoras, comerse los unos a los otros, ya que no existe justicia entre ellos; a los hombres, en cambio, les dio la justicia (dike) que es mucho mejor (áristos)». Cf. ibid., 192; Teogonía, 74.

${ }^{20}$ Homero: Iliada, II, 203-206. Cf. ibid., IX, 98-99. Respecto a la relación indisoluble establecida entre la voluntad divina (boulé) y la voz de Zeus, la manifestación discursiva de su thémis, véase Odisea, XVI, 402-403; Ilíada, V, 761-762.

${ }^{21}$ Recuérdese que la thémis y el agorá ocupan en el campamento aqueo el mismo espacio que los altares de los dioses (Ilíada, XI, 807-808), y que es Zeus quien ordena a Temis convocar las asambleas (Ibid., XX, 4). Cf. Odisea, II, 68-69: «Temis, deidad que reúne y disuelve las juntas que suelen tener los humanos». De ahí que Píndaro (Olímpicas, XIII, 6-8), al igual que Hesíodo (Teogonía, 901-902), señale a Temis como garantía del buen consejo (euboulía) y madre de la justicia (dike), de la legislación apropiada (eunomía) y de la paz (eiréne). De hecho, la etimología de «thémis» remite a la raíz indoeuropea *dhe- («poner», «arreglar», «disponer» u «ordenar»).

22 Cf. Homero: Ilíada, IX, 155-156. Véase Esquilo: Prometeo encadenado, 171, donde la timé y el skêptron definen la potestad del rey de los dioses. De él derivan por entero las regalías del basileús, 
No obstante, el hecho de que la comunidad de guerreros homérica sea fruto de la adjunción de distintos linajes de origen regio conlleva la instauración de un espacio político singularizado en el que la distribución jerárquica del poder público queda en suspenso, neutralizada en beneficio de la mejor decisión para el colectivo. La plaza comunitaria (agoré), en cuanto escenario de la divergencia, teje y multiplica las diferentes voces del discurso civil, y puede poner en entredicho la hegemonía del soberano. "Conforme a la ley de la asamblea (hé thémis est'agorêi)», concluye Diomedes, resulta legítimo oponerse (máchesthai) al criterio del ánax ${ }^{23}$. La práctica deliberativa trata de establecer una validez normativa cuyo sentido operativo no descansa en la asimetría del asentimiento a los criterios de acción impuestos contingentemente por el monarca, sino en la eficacia retórica de los implicados en el combate dialéctico de la asamblea. La obligatoriedad deontológica de la norma jurídica, como expectativa de comportamiento que restringe externamente el espacio de opciones del actor social, depende de su grado de imposición, de su mayor o menor aceptación en el círculo de la agoré. En la Grecia clásica, la legitimidad democrática del nómos emulará los rasgos coercitivos y consuetudinarios de la thémis arcaica; pero tratando de velar, en la medida de lo posible, el enfrentamiento (máche) originario de los derechos privados subjetivos que define el agón homérico, así como la preeminencia de la divinidad en la configuración del derecho.

\section{III}

Con todo, quisiéramos seguir abundando en este trabajo en la descripción de los valores, de las relaciones políticas y de los mecanismos enunciativos vinculados a la proclamación de la justicia en el mundo arcaico. Para ello, nos gustaría detenernos tanto en aquellas fuentes que confirman la autoridad del palaiòs nómos, como en aquellas que ponen en entredicho su influjo. Dichos textos suponen un momento de transición entre las «teonomías» arcaicas y la instauración de la lectura pública del nómos graptós como núcleo de la administración ciudadana. Por ello, creemos que dichos testimonios resultan paradigmáticos a la hora de ejemplificar el modo en que el orbe griego escenificó la ruptura de la norma consensual con la epifanía trágica del derecho de la phýsis.

En los Siete contra Tebas, por ejemplo, es Zeus Protector (alexetérios) quien cumple la función de hacer justicia, o, lo que es lo mismo, quien ejerce la omnipotencia (pankratesía) de su basileía. En calidad de nemétor, administra (nomizetai) la buena suerte (eutychía) de los defensores de la patria (dómoi), o la desgracia

pues -como señala el Himno homérico a las Musas y a Apolo- «los reyes proceden de Zeus» (v. 4). A propósito de las virtudes adivinatorias del bastón de mando, vid. Ilíada, I, 15; Odisea, XI, 91; Esquilo, Agamenón, 1265.

${ }^{23}$ Homero: Ilíada, IX, 32-33. Cf. J. L. Pardo, La metafisica, op. cit., pp. 39-41. 
(dystychía) de los mortales arrastrados por la incontinencia, el orgullo y la locura: tà hypéraucha. Su mirada (ephórasis) se muestra irritada con aquellos que emplean palabras vanas y altivas, y el vigor ígneo (pyrphóros) de sus rayos doblega las veleidades de la hýbris ${ }^{24}$. La voz que no celebra el nombre de quien observa y gobierna todas las cosas (hòs ephorâi pánta kaì kratýnei), del árbitro supremo del que todo depende (pánta kraínon), sufre los rigores de la fortuna (týche) ${ }^{25}$. El dominio de la elocución se orienta, por consiguiente, en función de un significante sagrado -el propio Zeus- que rige por completo la validez operativa del régimen discursivo. Al promulgar una ley, predecir el destino, entonar un himno o emitir un juicio, el hablante ha de velar por el carácter ajustado de su realización performativa. Para ello, deberá acomodar su entonación a los theôn nómoi. De lo contrario, la escansión de lo enunciado carecerá de ritmo y melodía: se convertirá en un ánomos nómos, en un canto desgraciado rebosante de adikía. Frente a ese desarreglo predicativo, que trastorna y deteriora la transición pautada de la divinidad, su devenir absoluto (aión), se hará patente aquello que siempre permanece y contrabalancea la falta de concierto de lo que hay: la ley sagrada (thesmós) destinada a que el culpable sufra (páschei) una reprensión capaz de reequilibrar el frágil reglaje de la matriz axiológica que prefigura y ordena el sentido de su mundo 26 . Esa «logonomía» suprema -ilocalizable, «atópica» y diferida de continuo por el acontecer polifónico del discurso-, se significa en la iterabilidad de la ley y constituye la economía léxica de sus posibles lecturas. Su voz se deja oír en cada nómos, en cada exégesis, en cada figura de derecho, y, a pesar de ello, la fuerza legisladora de la dicción divina, la soberanía de su pronunciación, permanece necesariamente innominada, intransitiva, sin acomodo en el esquema referencial o tropológico que define la predicación humana. Como contrapartida, su suspensión, su negativa a comparecer abiertamente en las sentencias coyunturales que urden la flexión disyunta de los lógoi, salvaguarda su poder intersticial, la violencia inaugural de su stásis.

Esa potencia trágica e incomprensible del nómos divino, su verdadera arché, reverbera en cada juicio, en cada enunciación: funda y confina simultáneamente el fuego y la luz de su libertad (eleuthería) ${ }^{27}$. Ahora bien, tal demarcación, destinada a deponer (apotrépein) a los dioses de la cólera (mênis) que ocasiona la adikía, adopta en la Grecia arcaica la forma de una reparación 28 . Como señalamos con anterioridad a propósito de las Erinias, el mal (nósos) ocasionado por un suceso

24 Véase Esquilo: Siete contra Tebas, 8, 255, 441-444 y 481-485.

25 Sófocles: Electra, 175; Esquilo, Euménides, 760. Cf. Esquilo: Suplicantes, 26.

26 Esquilo: Agamenón, 1560-1564. Cf. ibid., 1142.

27 Esquilo: Coéforas, 863-864. Respecto al sentido literal o metafórico de «pyr» y «phôs» en este pasaje (fuego de la celebración posterior al juicio de Atenea, de la procesión que cierra las Euménides o del hogar recuperado por Orestes), véase Garvie, A. F. (ed.): Aeschylus. Choephori, Oxford, 1986, pp. $282-283$

28 Ibid., 400-404: «Ley es, sí, que las gotas de sangre vertida en el suelo otra sangre exijan, porque la muerte invoca a las Erinias, agregando a una ruina otra ruina que arranca del muerto anterior». 
intolerable (álastos) ha de ser vindicado por un protector (palamnaîos) de la thémis. El estado de cosas que solicita esa intervención linda entre lo conflictivo y lo funesto, constituye una genuina aporía: a) cada nuevo muerto (neothnés) acrecienta el número y el resentimiento (ménima) de los afligidos y agraviados (dýsphrones), b) la concatenación de crímenes estorba la preceptiva kátharsis, y c) sólo la interposición de un dios puede dispensar el imperioso remedio (aké) que neutralice el ultraje (míasma) cometido por el desafortunado que suele devastar con su hýbris toda la ciudad29. Al menos, no es otro el escenario que ampara la aciaga huida de Orestes en dirección a Delfos. Después de su homicidio, cometido bajo el influjo de deseos (hímeroi) encontrados ${ }^{30}$, tan sólo la intercesión de Apolo puede dispensarle de rendir su albedrío al rencor de las Erinias. Para volver a ser puro (katharós), precisa ser absuelto del delito de sangre, algo inviable de seguir vigente la antigua lógica de la represalia, es decir, «el decreto (thesmós) que fijó (kraínei) el destino y dieron los dioses como aquello que inexorablemente se cumple» ${ }^{31}$. Necesita que Loxias reconduzca, ordene y vuelva a mostrarle (exegeîtai) el camino de la justicia. Sólo la voz, los gestos, la postura y las palabras del verdadero guía del buen consejo (exegetés tôn agathôn) le harán conocer «la ley de lo que será (thémis tôn mellónton)», el final del proceso (télos díkes) ${ }^{32}$. A modo de interpretación (exégesis), de lectura avant la lettre, el oráculo de Apolo muestra (semaínei) al suplicante una salida, le orienta (exegeîtai), traza un plan (diagráphei) que ilumine su corazón (thymós) y desempeña el cometido de abrirle paso, de guiarle (hegeîsthai) con la autoridad de quien conoce la dirección y el sentido, la modulación ajustada del lógos ${ }^{33}$. Por eso, su habla establece el nómos en cierne. La pujanza de la alocución de los exegetaí elegidos por el oráculo (pythóchrestoi) ${ }^{34}$ subvierte la disposición (táxis) normativa preexistente, esto es, se arroga una facultad judicativa. No es para menos: la potestad retórica del señor (despótes) de Delfos que guía a los intérpretes -el empuje (krátos) de sus palabras (lógoi), como denuncian las propias Erinias al comienzo de las Euménides ${ }^{35}$ - resulta sencillamente inmensa y holgada a la hora de transfigurar y reestructurar no sólo la transferencia de la timé, sino el reparto primitivo (palai-

\footnotetext{
29 Ibid., 278-284.

30 Ibid., 299-304.

31 Esquilo: Euménides, 391-393.

32 Sokolowski, F.: Lois sacrées des cités grecques. Supplément. École française d'Athènes. Travaux et mémoires des anciens membres étrangers de l'École et de divers savants, XI, 1962, nº 8; Aristónoo de Corinto: Peán délfico a Apolo, 13-16 y 22; Esquilo: Euménides, 243.

33 Esquilo: Euménides, 31-33, 595, 609. Sobre «diagráphein» y «diametreîsthai», cf. Lombardo, M.: «Le concezioni degli antichi sul ruolo degli oracoli nelle colonizzazione greca», art. cit., pp. 70-75 y Detienne, M.: Apollon le couteau à la main, op. cit., pp. 96-97, 109 y 232.

34 Platón: Leyes, 759 c-e. Cf. ibid., 738 b-d y 828 a; Crátilo, 407 b; Ion, 531 a.

35 Esquilo: Euménides, 163 y 227.
} 
genés) del destino (moîra $)^{36}$. Pues bien, dicha asignación va a purificar, ordenar y fundar, de la mano de Atenea y de la deidad de quien todo depende (Zeus), el nuevo ordenamiento que verá nacer el tribunal del Areópago. No está de más indicar que la designación de los jueces viene a reemplazar al palaiòs nómos que sembraba la discordia entre los distintos linajes de la pólis. Es decir, el acto locucionario del juez (dikastés), la nueva fuente de la enunciación legal, constituye una expresión realizativa destinada a punir y bloquear la stásis, la insurrección violenta connatural al antiguo modo griego de tramitar los conflictos de la comunidad política. La voz de los nómoi fijados por la escritura, de forma análoga al dictamen de la divinidad, se afana en refrenar la conflagración subrepticia que combustiona y anima la unión armónica de sus conciudadanos, el maridaje de lo disímil. El texto de Esquilo es tajante al respecto: el papel legislativo y epigráfico de las decisiones de la magistratura, llamado a prolongarse a lo largo del tiempo (chrónios), consiste en trasladar el pólemos allende las puertas de la ciudad. Al promulgar la ley, el choque solapado de intenciones y afectos heterogéneos que devana la avenencia colectiva se declara ausente (thyraîos), externo o ajeno al éros de la compenetración cívica: «iQue la guerra sólo sea exterior -nunca es difícil su presencia- y que exista en ella un apasionado amor por la gloria! [...] iQue jamás ruja en esta ciudad la discordia civil (stásis), siempre insaciable de desgracias!» ${ }^{37}$. Como resulta notorio, la eúkleia-el móvil primordial de la actuación pública- mana del mutuo afecto, de la philía de tò koinón -el cuerpo de leyes compartido- frente al krátos inquietante de la heteronomía.

Sin ninguna duda, ese rechazo de la supeditación de lo propio (idion) a lo ajeno -requisito genérico de la carta de ciudadanía helena-, ese miedo cerval de claudicar ante el otro, el extranjero o los refractarios al beneficio público (démios), encuentra su máxima expresión en la hamartía de Prometeo, reo de su filantropía y condenado por no haber aprendido a soportar (stérgein) el poder absoluto (tyrannis) de Zeus, esto es, su krátos y su bía, los ídioi nómoi con los que domina y gobierna (kratýnei) a los dioses de antaño ${ }^{38}$. Su delito consiste en haber alterado los canales de distribución de la timé implantados por el mónarchos, en mudar la regulación de su nuevo (neochmós) código. La inculpación (aitía) de hýbris atañe a todo aquel que franquea y desplaza el límite (péras) sancionado de la justicia, el extremo impe-

\footnotetext{
36 Ibid., 171-172. Cf. 727-728. Ha de subrayarse que la acción de Apolo, a juicio de las Erinias, atenta contra las costumbres de los dioses (parà nómon theôn). Es más, entraña la destrucción (kataphthorá) de la antigua ley $(778,808)$, de la partición de honores y privilegios que establecieran las viejas deidades. Cf. Lebeck, A.: The Oresteia. A Study in Language and Structure, Cambridge (Mass.), 1971, pp. 145-149.

37 Ibid., 864-865, 977-978. Cf. 311.

38 Esquilo: Prometeo encadenado, 9-11, 150, 403. Véase Unterberger, R.: «Der 'Gefesselte Prometheus' des Aischylos», en Hommel, H. (ed.): Wege zu Aischylos, Darmstadt, 1974, vol. II, pp. 352-366.
} 
rante del que emana la fuerza y la autoridad de la ley ${ }^{39}$. De ahí que esa torsión sentencie a Prometeo al sufrimiento (pêma) y al daño (adikía) que irroga el poder contrario (antípalos) de Zeus ${ }^{40}$. Al dispensar a los hombres un exceso de cháris, a fin de resarcirles de su endeblez (oligodranía) constitutiva, el hijo de Temis omite uno de los preceptos centrales que tornean el sentir griego: «¡Nunca la voluntad de los mortales violará el plan armonioso de Zeus!» 41 .

Sin embargo, ha de añadirse que su desmesura titánica, cuya punición se traduce en la requisa de la voz (phoné) y de la figura (morphé) de los hombres, en la soledad ignota que sólo conoce la persistencia del tormento sufrido sin cesar (aiei), convierte al népios, al carente de entendimiento, en un ser dotado de inteligencia (énnoia) y dueño de su razón (epébolos phrenôn $)^{42}$. Gracias a esa benevolencia (eúnoia) desmedida, el hombre deja de asemejarse al fantasma de un sueño y adquiere el conocimiento (gnóme) preciso para gobernar sus actos sin ceder ofuscado ante el dominio del azar. Pues bien, uno de los dones inmoderados que reportan tales dividendos a los mortales es justamente la escritura. Entendida como un mecanismo ingenioso (mechánema) surgido de la invención (exeúresis), como resultado de la aplicación de una pericia técnica, la unión (sýnthesis) de los grámmata permite a los hombres atesorar la mnéme de todo. El encuentro (apántesis) de las letras, su conversación, propicia y conserva el recuerdo del pasado, tal como hiciera con anterioridad Mnemósine, la madre de la musas (mousométor), convertida ahora en una sobresaliente artesana (ergáne) 43 . No obstante, ese hábil hallazgo (sóphisma), fruto del ultraje vesánico (hybristés) del ascendiente de Zeus sobre la ceguera de los hombres, excede la justa medida (kairós), va más allá (péra) de lo tempestivo ${ }^{44}$. Se trata de una téchne de origen impío, surgida de la hýbris de un titán y capaz de encerrar entre sus líneas el poder de la memoria sagrada. Cada letra subraya su desavenencia con la economía discursiva precedente y con las relaciones de poder que orientan la política de la verdad arcaica. Por ello, al igual que sucedía con el nómos del tribunal del Areópago, el simulacro de la escritura pone de manifiesto simultáneamente la disociación, el desacoplamiento y la necesidad de concertar una transición incruenta entre facciones, grupos de poder y formas de vida discordantes. Como veremos posteriormente, la dinámica combinatoria del mecanismo gráfico

\footnotetext{
39 Ibid., 30, 47, 82, 150 y 324.

40 Ibid., 276, 472 y 528. Cf. Lloid-Jones, H.: «Zeus bei Aischylos», en H. Hommel (ed.): Wege zu Aischylos, op. cit., vol. I, pp. 265-300.

41 Ibid., 550-551: «oúpote tàn Diòs harmonían thnatôn parexíasi boulaì». Cf. Suplicantes, 86-111; Agamenón, 160-183. A propósito de la polémica relación entre cháris y bía, entre la gracia y la violencia que define en Esquilo el trato de los mortales con los dioses, véase Reinhardt, K.: Aischylos als Regisseur und Theologe, Bern, 1949, cap. I.

42 Ibid., 21, 26 y $442-444$.

43 Ibid., 459-461 y 469.

44 Ibid., 82, 507 y 970.
} 
estaba llamada a incidir en esa reconversión y en esa ruptura. Las tragedias de Esquilo escenifican ese desplazamiento del antiguo nómos tês phýseos y su adaptación a los nuevos dispositivos enunciativos de la alétheia. Podría decirse que la presunción inventiva de Prometeo personifica y compendia la asébeia encubierta de una comunidad política que yuxtapone de manera furtiva a lo largo del siglo V sus propias normas escritas (tà graptá) a las leyes (thesmoi) de la Díke ${ }^{45}$. Asimismo, resulta significativo el hecho de que «thesmós»-la ley natural establecida por los dioses, por aquellos que, en principio, por principio, siempre permanecen (oi aei óntes) - acabara mudando de sentido y equiparándose por extensión a la ley escrita ${ }^{46}$. Sería del mayor interés diagnosticar el papel que desempeñó la escritura en esa traslación semántica, al mismo tiempo que tratamos de esclarecer las estrategias interpretativas y las prácticas sociopolíticas que patrocinaron y condicionaron dicha analogía funcional.

\section{IV}

Antes de abordar la posibilidad de ese análisis, quisiéramos detenernos aquí en las Odas de Píndaro. Su concepción de la ley como potencia divina resulta modélica a la hora de detallar el marco jurídico de la basileía dórica, regentada por la violencia legítima (dikaía) del Cronión y la eunomía de la sabiduría délfica ${ }^{47}$. Al igual que en Hesíodo, el carácter verídico (étymos) de los lógoi regios, su cumplimiento (teleiótes), precisa el respaldo de Zeus. El basileús gobierna o dicta (némei) correctamente la suerte de sus ciudadanos cuando su discurso enaltece el orden sagrado (semnòn nómos), esto es, cuando su phoné reproduce y reanuda la venerable melodía compuesta por la divinidad48. Para ello, tendrá que saber escuchar el kélados de la ley, la voz nítida y sonora de naturaleza oracular que armoniza los acordes de la phýsis. Al prestar oídos (akoúein) al nómos, el poeta, el vate o el legislador harán resonar bellamente la ordenación divina (thémis). Sólo ese phónema será susceptible de ser inmortal (athánatos) 49 . La conexión entre el acto legislativo (nomothétesis), la adivinación profética (mantosýne) y la declamación poética (moûsa) es plena.

\footnotetext{
45 Esquilo: Suplicantes, 708-709. Cf. Euménides, 391.

46 Sófocles: Antígona, 801; Platón: Cartas, 355 c.

47 Cf. Schroeder, O.: «Nómos ho pánton basileús», en Philologus, $\mathrm{n}^{\circ}$ 74, 1917, p. 200.

48 Píndaro: Píticas, I, 67-68; III, 70; Nemeas, I, 72.

49 Píndaro: Himnos a los dioses, fr. 35 c; Ístmicas, III/IV, 58-59: «Porque inmortal prosigue resonando algo cuando lo dice uno bellamente (toûto gàr athánaton phonâen hérpei, eí tis ê̂ eípei $t i) » . C f$. Olímpicas, IX, 2; Ístmicas, IX, 4-5. Incluso el discurso ajustado (orthós) de un mensajero puede llegar a engrandecer a las Musas (Píticas, IV, 279). Véase Braswell, B. K.: A Commentary on the fourth Pythian Ode of Pindar, Berlin/New York, 1988, pp. 379-380.
} 
En los tres casos, nos encontramos con un tesoro (thesaurós) o con un fármaco (ákesma) derivado de la posesión maniática, es decir, con formas de canto (nómoi) dispensadas por la voz de Delfos: «También Apolo, contra graves dolencias, da (némei) remedios a hombres y mujeres, y dispensa la cítara, y concede la Musa a quien le place, el orden pacífico de las buenas leyes (eunomía), orientando a las almas, y rige la gruta del oráculo (mantéion)» 50 . La manía apolínea aglutina y coordina los distintos tipos de exégesis. Su phoné cumple el cometido de guiar (exegeîsthai) a aquel que sabe "escuchar (akoúein) la voz que ningún engaño (pseûdos) conoce» 51 , es decir, la elocución oracular. A su vez, la jerarquía vocal o sonora que descifra y estipula la mantosýne permite discriminar entre el entendido (synetós) y el ignorante cuyo lenguaje (gêrys) resulta ineficaz (ákrantos) contra las disposiciones de Zeus. La léxis del aedo inspirado al que asiste la Musa, concedida por el conocimiento adivinatorio de Apolo, constituye uno de los casos más evidentes de sophía frente a aquellos que, por el contrario, cifran su presunta locuacidad (panglossía) en la experiencia o en el aprendizaje (máthos): «Muchos rápidos dardos -sentencia el propio Píndaro- tengo debajo de mi codo, dentro de la aljaba, que alzan su voz para los inteligentes (phonáenta synetoîsin); pero que para la masa necesitan intérpretes (es dè tò pàn hermanéon chatízei). Sabio es el que conoce muchas cosas gracias a la naturaleza (sophòs ho pollà eidòs phuâi); los que conocen, empero, por adiestramiento [...] graznan en vano con charlatana lengua contra el ave divina de Zeus» 52 . El canto del poeta, respaldado por la gnóme y la justicia sacra (eusebès thémis) de Apolo, trata de hacer suyas las modulaciones del chresmós profético que revela el orden ajustado (hósios) del medio natural. Su dulce mélos se trenza en las almas de los sabios y acrecienta su fama al mismo tiempo que distribuye la gloria (kýdos) entre los hombres ${ }^{53}$. Naturalmente, esa acción laudatoria y judicativa, que determina el estatuto y la categoría de lo nombrado, pretende asemejarse al régimen de asignaciones implantado por la divinidad. Para Píndaro, también el cantor recita en sintonía con el proyecto imperecedero de Zeus, quien da destino (moîra) a los asuntos humanos de acuerdo con su propia eunomía ${ }^{54}$. Es más,

50 Píndaro: Píticas, V, 63-69. Cf. Peanes, fr. 52 a 10; Píticas, VI, 7/8; IX, 29; Olímpicas, VI, 65; Ístmicas, VI, 51; Esquilo: Euménides, 60-63: «Lo que ocurra a partir de ahora es cosa de Loxias, el muy poderoso señor (despótes) de este templo, pues es adivino que cura (iatrómantis), conocedor del porvenir (teraskópos) y purificador de las cosas ajenas (kathársios)».

51 Píndaro: Olímpicas, VI, 66-67.

52 Ibid., II, 83-88.

53 Ibid., I, 8-9. Vid. Gerber, D. E.: Pindar's Olympian One: A Commentary, Toronto, 1982, pp. 25-29, donde se describe cómo la oda de Píndaro trata de captar y envolver (amphibállein) la mêtis del auditorio. Cf. Nemeas, VII, 20-23; Píticas, IV, 66. Para Safo, también el canto melifluo que se conforma con la thémis encuentra su sede en el ốkos de las Musas: fr. 150. Cf. fr. 71, v. 6; fr. 185. En uno de sus fragmentos, Timocreonte de Rodas resume el vínculo que trata de establecer todo poeta heleno entre el canto (mélos), la gloria (kléos) y el derecho (dike): «Musa, dale fama a esta canción entre los griegos, como es propio y justo» (fr. 2).

54 Píndaro: Nemeas, IX, 29-31. 
sus composiciones alaban y ensalzan esa distribución armónica, buscan correr parejas con la melodía del kósmos. Basta con detenerse en un célebre pasaje de su quinta Ístmica, para verificar la función alícuota y equitativa que cumple el Cronión: «Zeus da lo uno y lo otro. Zeus, el señor de todo (Zeùs tà te kaì tà némei, Zeùs ho pánton kýrios)»55. Por su parte, la propia gradación de las sílabas del poema trata de nombrar la potencia activa de esa disposición coyuntural que el griego llama «Diós». Cuando el acoplamiento entre la manifestación de lo sagrado (tò ierón) y su valor normativo (hósios) es perfecto, esto es, cuando la sínfisis entre la actividad divina y el ejercicio consentido del ritual poético realza la soberanía del pátrios nómos ${ }^{56}$, se establece un enlace efectivo de carácter simbólico en el que acontece la revelación del orden de la divinidad, el carácter teofánico de la síntesis nómica. Evidentemente, esa ensambladura «verbal» no constituye un lazo biunívoco entre instancias afines e intercambiables, sino el desdoblamiento de la cesura matricial que presupone la efusión profética. La trascendencia congénita de la sacralidad, su incomparecencia constitutiva, es el requisito fenomenológico indispensable de su trágica determinación conceptual. Los nómoi de la representación poético-religiosa, artífices de esa frangible nominación, tienden un puente exegético entre la enérgeia hierofánica y el decurso histórico de la pólis. Sus categorías se nutren de ese hiato hermenéutico, es decir, la reserva presencial del krátos originario interviene como su más necesaria condición de posibilidad. La «dinámica» que gobierna la phoné del pánton kýrios -la lógica que desborda toda configuración mítica- permanece velada imperativamente. Se trata del sustrato ontológico que escande no sólo la acción legislativa de los dioses, sino la jurisprudencia simbólico-sacrificial de las magistraturas. A todas luces, nos referimos al principio rector que apresta y gradúa la profusión del lógos del ser: «La ley, rey de todos, de mortales e inmortales, condenando la suma violencia, lo guía todo con soberana mano» 57.

Al contrario de lo que defienden algunos intérpretes de tan célebre y controvertido pasaje ${ }^{58}$, el nómos basileús pindárico no puede confundirse con un mero hábito refrendado por la costumbre. Cuando el poeta pretende hacer referencia a la

\footnotetext{
55 Píndaro: Ístmicas, V, 52-53. Véase Bowra, C. M.: Pindar, Oxford, 1964, pp. 44-45.

56 Véase Rudhardt, J.: Notions fondamentales de la pensée religieuse et actes constitutifs du culte dans la Grèce classique, Paris, 1992, pp. 29-37; Pirenne-Delforge, V.: «Religion grecque», en Y. Lehmann: Religions de l'Antiquité, op. cit., pp. 144-145.

57 Píndaro, fr. 169 a: «Nómos ho pánton basileús thnatôn te kaì athanáton ágei dikaiôn tò biaiótaton hypertátai cheirì). El resto del poema, conservado parcialmente (Pap. Ox., 1961, 26, nº 2450), respalda la justa violencia de la que se sirvió Heracles para robar los bueyes del gigante Gerión. $C f$. Theiler, W.: «Nómos ho pánton basileús», en Museum Helveticum, nº 22, 1965, pp. 69-80.

58 Ostwald, M.: «Pindar, nómos, and Heracles», en Musgrave, W. y Stern, J. (eds.), Pindaros und Bakchylides, Darmstadt, 1970, pp. 194-231; Ehrenberg, V.: «Anfänge der griechischen Naturrechts», en Archiv für Geschichte der Philosophie, n 35, 1923, pp. 119-143; Pohlenz, M.: «Nomos», en Philologus, $\mathrm{n}^{\circ}$ 97, 1948, pp. 135-142 y «Nomos und Physis», en Hermes, nº 81, 1953, pp. 418-438.
} 
diversidad de usos, prácticas y formas de vida que conforman la tradición helena, prefiere emplear el plural «nómina»59, que designará más tarde el conjunto de reglas legales promulgadas por cada comunidad política (nómaia, nomizómena). El uso de la noción de «nómos» atiende más bien al orden sagrado (semnós) fallado por la divinidad, como puede apreciarse al final de la primera Nemea, donde los actos heroicos de Heracles se constituyen en alabanza (aíne) del poder del Cronión 60 . De hecho, la mano sagrada que indica y guía (ágei) las acciones de los mortales y de los inmortales -salvo que pensemos que Píndaro cae en una impiedad que desmiente por doquier el resto de sus composiciones- no puede ser otra que la de Zeus. La fuerza legítima (dikaía) de sus gestos encarna la voluntad omnipotente del basileús que determina la sucesión de los acontecimientos y la distribución de las prerrogativas, condenando tà bíaia, la violencia contestataria que pretende comprometer el orden soberano (hypértatos). Al igual que el polyképhalos nómos, inventado por Atenea y concedido a los mortales a modo de merced61, el nómos basileús constituye la ofrenda mediante la que ho pánton kýrios muestra, ejerce y materializa «la salvadora y muy gloriosa Eunomía» ${ }^{62}$. En ambos casos, se trata de una realización divina destinada a regular la prâxis del colectivo político-religioso. Conforme a ese marco sagrado, que ampara el crecimiento saludable y la estabilidad de la comunidad, habrán de llevarse a cabo todos los actos cúlticos y judiciales de los cuerpos colegisladores. De ese modo, podrá darse una integración ritual de los derroteros de la pólis en los cauces atemporales de la phýsis, representados de forma arquetípica por el carácter sacro de la divinidad.

\section{V}

En ese mismo círculo de ideas, puede encuadrarse la concepción de la ley que presentan los fragmentos de Heráclito. Afín a la autoridad orgánica que disfruta el nómos basileús, la eterna potestad del theîos nómos al que rinde culto el filósofo de Éfeso - la necesidad imperiosa de su krátos - tutela y acaudilla la proliferación de los nómoi que articulan la multiplicidad diferenciada del dêmos. La fuerza (ischýs)

\footnotetext{
59 Píndaro, fr. 215 a 2-3: «Los unos tienen estas costumbres (nómina), aquéllos otras, y cada cual enaltece su propia justicia (dike)».

60 Píndaro: Nemeas, I, 71-72.

61 Píndaro: Píticas, XII, 22-23. Véase von Wilamowitz-Moellendorff, U.: Pindaros, Berlin/Zürich/ Dublin, 1966, pp. 143-146. Como señala Estrabón (Geografia, IX, 3, 10), el polyképhalos nómos debía su nombre a las distintas secciones que conformaban el canto pítico, entre las que se encontraban el pronómion, los íamboi y los dáktyloi. Cf. Laroche, E.: Histoire de la racine «nem-» en grec ancien, Paris, 1949, pp. 168 y 208.

62 Píndaro: Olímpicas, IX, 15-16. Cf. XIII, 6. Véase Gigante, M.: Nómos basileús, Napoli, 21993, pp. 72-102.
} 
del conjunto cívico, su independencia y su soberanía dependen de la captación intelectual (phrónesis) de aquello que pertenece a todos: la ley común (xynós) que trama, nutre y aviva la decisiones públicas y la jurisprudencia ciudadana, es decir, el lógos sabio y verdadero que atesora, manifiesta y declara la gnóme divina ${ }^{63}$. Como puede apreciarse, la relación de determinación entre la disparidad de los nómoi y la naturaleza categórica de su raíz ontológica resulta terminante, dado que la posible autonomía del colectivo político se encuentra sometida a la heteronomía absoluta que impone lo numinoso. Mientras que lo común (koinón) lo es en la medida en que constituye la conexión universal del kósmos ${ }^{64}$, las leyes humanas por sí solas, sin obedecer a su propia matriz, no pueden realizar la unificación de la diversidad consuetudinaria que siembra la discordia (éris) en la ciudad. Por ello, la universalidad sincrónica (tò xynón) y la subsistencia diacrónica del lógos divino, de aquello que siempre (aei) perdura, son la condición sine qua non del compendio efectivo y perspicaz (xýn nóoi) de los usos que fija o aquilata toda legislación humana. El pasaje al que nos estamos refiriendo reza lo siguiente: «Los que hablan con inteligencia tienen que fortalecerse, necesariamente, con lo común a todos, como la ciudad con la ley, y con mucha más fuerza, pues todas las leyes de los hombres se nutren de una sola, la divina, que domina tanto como quiere, basta a todas y prevalece sobre ellas» 65 . De manera palpable se deja notar cómo lo presuntamente universal, la norma divina, singular en el fondo, parece alcanzar y sobrar para alimentar la totalidad de las singularidades. En esta relación entre singularidades enfrentadas, es donde se juega la validez de la ley, su legitimidad, donde radica la efectiva quaestio iuris, inseparable, en este marco, de su acontecer, de cómo se produce, de su quaestio facti.

Asimismo, ha de subrayarse que esa unicidad del theîos nómos, la lógica eterna de hén tò sophón que dirige y determina (oiakizei) el rumbo de lo ente katà tòn lógon66, enlaza diferenciando pánta dià pánton, la multiplicidad genética de las cosas, sus apariciones diferenciadas. La basileía del rayo o del fuego que rige esa

63 Heráclito, fr. 1, 2, 41 y 78.

64 Ibid., fr. 89. A. García Calvo aproxima el sentido del término «kósmos» (ordenación del mundo) a la noción de «phýsis», entendida como modo de ser de las cosas en general, lo que acentúa la dimensión lingüístico-ontológica de la dialéctica de la unidad de los contrarios heraclítea. Al respecto, véase del autor Razón común, Madrid, 1985, p. 45.

65 Ibid., fr. 114. Véanse Held, K.: Heraklit, Parmenides und der Anfang von Philosophie und Wissenschaft. Eine phänomenologische Besinnung, Berlin, 1980, pp. 137-143; Bollack, J. y Wismann, H.: Héraclite ou la séparation, Paris, 1972, pp. 316-318; García Quintela, M. V.: El rey melancólico. Antropología de los fragmentos de Heráclito, Madrid, 1992, pp. 137-144.

66 Ibid., fr. 1, 41, 50 y 64. Véase Heidegger, M. y Fink, E.: Heraklit. Seminar Wintersemester 19661967, Frankfurt, 1970, pp. 9-46. Trad. cast.: Heráclito, Barcelona, 1986, pp. 7-37. Tanto para Heidegger como para Fink, la conformación del mundo (Weltbildung), esto es, la totalidad de las cosas finitas delimitadas se muestra a través (diá) de la unidad compendiante (hén) que saca a la luz y reúne en sí lo mucho global, tà pánta. 
unificación esencial de lo intramundano -señala el propio Heráclito- «quiere y no quiere ser llamada con el nombre de Zeus» 67 . De hecho, se escande en otra relación de copertenencia entre onómata tan dispares como el tiempo eterno (aión) y el combate armado (pólemos) ${ }^{68}$. En cualquier caso, siempre se alude a la acción de un monarca o de un legislador que distribuye, diferencia y hace surgir (gignesthai) todo dentro de sí, en su enfrentamiento agonal e imperecedero, conforme a la articulación compleja del lógos del nóos divino. De ahí que se defina el nómos del siguiente modo: «La ley consiste también en obedecer la voluntad de uno solo» 69 . Para Heráclito, el hombre dotado de piedad e inteligencia sabe que la fundamentación de las normas de la pólis responde a la boulé del theîos nómos, a la naturaleza de las cosas, al orden del mundo impuesto por Zeus. Quien se muestre capaz de aprehender que el carácter realizativo del código laico emana de la decisión determinante de ese gobernante único podrá evaluar y deliberar con sentido en torno a los asuntos comunes, esto es, podrá desempeñar a su vez el papel de legislador, advirtiendo los errores y las fisuras de la actividad nomotética precedente. Al afianzarse en el valor universal de las directrices de la phýsis, su consejo suscitará el consenso y la aprobación que suelen ratificar la validez instrumental de las leyes de los hombres. Por tanto, esa aceptación en lo común de la creencia compartida no consistirá únicamente en atenerse a los usos de los antepasados, sino en encarar positivamente la defensa de los aspectos cohesivos y centrípetos de las nuevas propuestas legislativas. Al respecto, traemos a colación el siguiente pasaje: «Es necesario que el pueblo luche por su ley, por la que acontece, como por la muralla» ${ }^{70}$. A nuestro juicio, el acento de la proposición recae en el uso que se hace de «gígnomai» («llegar a ser», «acontecer», «tener lugar», etc.) en la acotación «hypèr toû ginoménou», suprimida indebidamente en algunas ediciones clásicas como la de Diels y Kranz ${ }^{71}$. Dicho verbo, que supone de forma explícita el sentido de desarrollo en un continuum temporal 72 , hace hincapié en el devenir de la ley, en la dinámica vital de la comunidad política. El dêmos no ha de velar por la inmovilidad del código, sino

67 Ibid., fr. 30, 31, 32, 64, 66, 76 y 90.

$68 \mathrm{Ibid}$., fr. 52: «El tiempo (aión) es un niño que juega a las damas: el reino (basileíe) de un niño»; fr. 53: «La guerra (pólemos) es el padre (patér) de todas las cosas, el rey de todas (pánton dè basileús), y a unos designa como dioses, a otros como hombres; a unos los hace esclavos, a otros libres».

69 Ibid., fr. 33: «nómos kaì boulêi peithesthai henós».

$70 \mathrm{Ibid}$., fr. 44: «máchesthai chrè tòn dêmon hypèr tô̂ nómou hypèr toû ginoménou hókos hypèr teícheos». Respecto a la importancia del «hacer» en Heráclito y en clara correspondencia con el sentido del verbo «gígnomai» que nos ocupa, véase Lledó, E.: El concepto "poíesis» en la filosofía griega, Madrid, 1961, pp. 18-26.

71 Diels, H. y Kranz, W.: Die Fragmente der Vorsokratiker, Berlin, 61951-1952.

72 Eggers Lan, C.: Las nociones de tiempo y eternidad de Homero a Platón, México, 1984, p. 88; Martínez Nieto, R. B.: La aurora del pensamiento griego, Madrid, 2000, pp. 46-47. Cf. Heráclito, fr. $1,7,20,36,39,44,56,63,77,80$ y 110 . 
por la correcta metamorfosis del sistema de relaciones sociales, por la norma que acontece o se forja paulatinamente en el seno de los órganos institucionales. Los cimientos por los que hay que combatir, en consecuencia, son profundos y cambiantes, como las lindes de la ciudad, y obedecen a la lucha interna que congrega o divide los intereses del grupo social. La verdadera muralla de la pólis es la lógica inmanente del combate que funda tò koinón, el agón que transforma el espacio de posibilidades compartido en un organismo consistente que se autorregula en función de un complejo axiológico diferenciado.

Nos gustaría señalar que la lúcida comprensión del lógos alethés que favorece ese estado de cosas es completamente acústica. Precisa la areté del oyente -el ejercicio de la sophrosýne- y su atenta escucha a los ritmos de la naturaleza. Ese oído privilegiado le reportará la sabiduría (sophía) que, a su vez, le capacitará para decir cosas verdaderas (alethéa légein) ${ }^{73}$. Su epistéme será fruto de su capacidad auditiva. Es más, ni siquiera podrá hablar (eipeîn) sin meditar con esmero el sentido de lo escuchado y, al igual que el népios, el adolescente que no puede intervenir en la asamblea, si se niega a tratar de oír la voz del theîos nómos, siempre quedará aherrojado a la futilidad de las opiniones humanas (tà anthrópina doxásmata) ${ }^{74}$. La adquisición de conocimiento, como es preceptivo en una cultura que sigue siendo preferentemente oral, pasa por atender a los discursos de los demás con el objeto de lograr un acuerdo (homologeîn), esto es, de convenir en qué medida las sentencias que se ponen en juego se corresponden con el lógos primigenio. Por tanto, para conocer (ginóskein) la constitución de las cosas, su phýsis, será imprescindible saber escuchar (akoúein) la melodía de ese nómos eterno que define el movimiento y la articulación de lo múltiple diferenciado. Dicha empresa -irrealizable sin la mediación de un theîos anér que, a modo de daímon, sea capaz de salvar la formidable distancia que separa el êthos humano de la gnóme divina 75 - puede acometerse de dos formas extremas y desiguales, aunque estrechamente emparentadas. Bien como philósophos, en cuyo caso se tratará de mostrar en detalle o de explicar (phráxein) mediante la palabra los elementos constitutivos de cada cosa según su naturaleza (katà phýsin) ${ }^{76}$-método que bosqueja y preludia la diaíresis platónica-, o bien en calidad de prophétes, de instrumento de la divinidad. En ese último caso, será el propio dios quien se comunicará a través de la boca delirante del alma posesa. Como en el caso de la Sibila, su stóma se pondrá al servicio del semaínein divino y

73 Heráclito, fr. 112: «Pensar bien, la mayor virtud; y la sabiduría, decir la verdad y obrar según la naturaleza, escuchándola (sophroneîn aretè megíste, kaì sophie alethéa légein kaì poieîn katá phýsin epaíntas)». Véase el comentario que hace $\mathrm{M}$. Conche de este pasaje en su edición francesa (Héraclite: Fragments, Paris, 1986, pp. 234-236).

74 Ibid., fr. 19, 70 y 79.

75 Ibid., fr. 78 y 83 .

$76 \mathrm{Ibid}$., fr. 1, 35. Respecto al papel central que desempeña el verbo «akoúo», véanse asimismo los fr. $19,34,50,79$ y 108 . 
recitará involuntariamente sus prescripciones. Es más, en el transcurso de la vocalización, el movimiento de sus labios será Apolo. Sólo gracias a este último (dià tòn theón), su phoné será capaz de atravesar el flujo temporal con el objeto de dar lectura a los cauces del porvenir 77 .

De igual manera, parece obvio que la sophía que apetece Heráclito -ceñida, como hemos visto, a la expansión retórica y a la dialéctica de la entonación y de la escucha- no puede destilarse de la composición escrita (syngraphé). A sus ojos, comparada con la efusión verbal, la escritura sólo es un arte fraudulento y engañoso (kakotechnía) que propicia la polymathía, un exceso de erudición que aglutina de forma ecléctica todo tipo de conocimientos sin percibir su estructura lógica ni adoptar una posición definida ${ }^{78}$. Ha de señalarse que el volumen en prosa de la época, consistente en una compilación con fines mnemotécnicos de definiciones, aforismos significativos y enunciados sumarios, no representaba todavía una fuente de sabiduría legítima. Sólo se trataba de un guión o de un esquema formulario que ayudaba al desarrollo de la exposición oral, es decir, al adecuado decurso del lógos 79. Entre finales del siglo VI y la primera mitad del siglo V, el papel desempeñado por la escritura, pese a la creciente difusión del alfabeto, siguió siendo accesorio y circunstancial $^{80}$. La prioridad correspondía a las resonancias de la palabra hablada y a los valores retóricos, estéticos y religiosos asociados a la comunicación discursiva, a una verdadera política de la escucha.

Tanto en el caso de la ley como en las manifestaciones del lenguaje revelado nos encontramos con una distribución oral de carácter poético-religioso en la que la entonación de la verdad se aviene a una jerarquía establecida que determina los límites de su representación ritual. El sentido de ese discurso acontece y se cumple necesariamente en virtud de la fuerza de la palabra remitida originariamente por la divinidad. El poder de su arché determina por completo sus posibles efectos y sanciona la validez de cada situación. En ambos casos, el acto de habla opera como una declaración representativa, como una expresión realizativa capaz de condicionar performativamente a sus oyentes y de reconocer el carácter definitivo, justo y acer-

77 Ibid., fr. 92: «La Sibila, con su boca delirante, sin sonrisas ni maquillajes ni perfumes, atraviesa mil años con su voz, gracias a la divinidad (Síbylla dè mainoménoi stómati agélasta kaì akallópista kai amýrista phthengoméne chilion etôn exikneîtai têi phonêi dià tòn theón)».

78 Ibid., fr. 129: «Pitágoras, hijo de Mnesarco, practicó la investigación (historie) más que los demás hombres, y con lo que extrajo de esos escritos formó su propia sabiduría (sophie): mucha erudición, arte fraudulento»».

79 West, M. L.: Early Greek Philosophy and the Orient, Oxford, 1971, pp. 5-6; Havelock, E. A.: Preface to Plato, Cambridge (Mass.), 1963, p. 170.

80 Véanse Harvey, F. D.: «Literacy in the Athenian Democracy», en Revue des études grecques, $\mathrm{n}^{\circ} 79$, 1966, pp. 585-635; Nieddu, G.: «Alfabetismo e diffusione sociale della scrittura nella Grecia arcaica e classica: Pregiudizi recenti e realtà documentaria», en Scrittura e Civiltà, n ${ }^{\circ}$ 6, 1982, pp. 233-261; Detienne, M.: «L'espace de la publicité, ses opérateurs intellectuels dans la cité», en Les savoirs de l'écriture en Grèce ancienne, op. cit., pp. 29-81. 
tado de aquello que se enuncia. Esa singular dimensión ilocucionaria se traduce en una emisión de signos que efectúa su propio referente: tà phýsei ónta. En última instancia, se trata de una inflexión prosódica que reafirma la lógica del orden sagrado de la naturaleza. Tanto el canto como la lectura nombran de viva voz el vigor, la belleza y la verdad de su prâxis.

\section{VI}

Dicha distribución de sémata recibe el nombre de nómos. Desde Homero, el verbo «némo» se emplea para describir el acto ritual de entrega de bienes en el que un personaje importante dispensa a sus invitados diversos regalos o viandas. La descripción meticulosa de los gestos del oferente y el celo con el que se detallan las actitudes de los comensales ponen de manifiesto el sentido solemne y ceremonial de la partición. Esa adjudicación entraña la división de un todo en sus partes y el ordenamiento de cada transferencia de haberes o poderes. Como puede apreciarse, entre el fraccionamiento, la donación y la administración, la semántica de la raíz indoeuropea $*$ nem- incide en el carácter de asignación y de señalamiento del canto y de la ley 81.

De ahí que la acción de determinar el curso de los acontecimientos, como hemos visto con anterioridad, se encontrase bajo el dominio de ese mismo verbo. Uno de los elementos esenciales del empleo de «némo», junto al hecho de administrar y compartir, era el modo específico de acometer esa acción: el conjunto de ademanes que acompañaba la donación del agente principal y la recepción de los concurrentes. Pues bien, la afirmación reiterada de esa jerarquía gestual entre el que posee y sus recipiendarios se produce igualmente en la distribución del destino que lleva a cabo la divinidad al sortear los lotes del daímon o de la moîra: «Zeus el olimpio concede (némei) en persona la dicha a los hombres, a los perversos y a los honrados, a cada uno según su parecer» 82 . A su vez, quien administra el hado, «posee», «disfruta», «explota» o «habita» el témenos que se ha adjudicado o atribuido en cuanto mandatario o mentor, como acentúa el uso de la voz media «némomai» ${ }^{83}$. Al imperar (némein) en ese terreno sagrado, la división que ejerce, sostiene y realiza permite que cada cosa encuentre su lugar en el kósmos.

Dicho acomodo armónico es eminentemente oral o, mejor dicho, se amolda al discurrir de la phoné. En la práctica de la mantosýne -exponente privilegiado del

\footnotetext{
${ }^{81}$ Laroche, E.: Histoire de la racine «nem-» en grec ancien, op. cit., pp. 7-9; Roberts, E. A. y Pastor, B.: Diccionario etimológico indoeuropeo de la lengua española, op. cit., p. 114.

82 Homero: Odisea, VI, 188-189.

83 Cf. ibid., XI, 185-186; Ilíada, XII, 313; XX, 184-185; Himno homérico a Afrodita, 97. Véase Shipp, G. P.: Nómos Law, Sydney, 1978.
} 
lógos alethés que fragua ese ordenamiento-, el verbo que da cuenta de la distribución vocálica de Apolo vuelve a ser «némo»84. La idea de detentar el poder, en el caso de la palabra revelada por el dios, se añade a la imagen homérica del reparto colectivo. Por ello, el acto de conferir honores (timèn o chárin némein) -expresión recurrente en el lenguaje de los trágicos que suele ir ligada a la obsequiosidad de lo divino 85 - irá unido al hecho de administrar y gobernar la ciudad (némein pólin). Para regir la comunidad y tener ese sentimiento pleno de fuerza respecto del propio discurso que precisa todo legislador, resultará imprescindible poseer una presciencia infalible (prónoia), es decir, disponer la lengua (glôssan némein) según lo dispuesto por el destino (týche). No es otra la facultad que nos permitirá designar con acierto lo real, esto es, decir la verdad (légein etétyma), proferir un nombre (ónoma) totalmente acorde (panetétymos) a la esencia de lo mentado 86.

Ese conocimiento, efecto del enlace inmediato con el estrato máximo de todos los órdenes de relación posibles, con el testaferro supremo de toda dignidad acústica, se traducirá en un dominio espléndido de la phoné. Cuenta el Himno homérico a Apolo que las jóvenes de Delos que servían al dios, eran capaces de imitar a la perfección el habla de todos los hombres. La belleza de su canto (aoidé) se ajustaba con fidelidad a la prosodia más extraña. Al producirse tan sorprendente mímesis, el oyente tenía la sensación de estar escuchando su propia voz, aun cuando se tratase de un extranjero y su lengua fuese desconocida de todos, un mero «balbuceo» para el sentir griego 87 . El taumaturgo que impulsa ese fascinante fenómeno, el hermoso sonido (audé) del arco de Apolo ${ }^{88}$, signa (semaínei) la convertibilidad del lenguaje y rige (némei) su orden discursivo. Por otra parte, al herir las cuerdas de su lira, mide y acompaña la articulación ajustada del lógos: su secuencia fónica y el carácter discreto de su léxis. La proximidad semántica entre el sentido político-religioso de esa distribución nómica y su dimensión marcadamente musical puede encontrar su razón de ser en la práctica de la exégesis legislativa, en la lectura efectiva de la ley.

En el marco de las teonomías arcaicas, como hemos visto, la justicia y el derecho derivan exclusivamente de la sonoridad coercitiva de la divinidad. En la épica homérica, no existe un imperativo fundamentado racionalmente al margen de los decretos sagrados o de las prescripciones rituales, ni una concepción jurídica de la díke o de la thémis. La primera parece designar el comportamiento respetuoso con las instituciones divinas; la segunda, la aplicación pautada de los usos ancestrales

\footnotetext{
84 Esquilo: Euménides, 716.

85 Cf. ibid., 624; Sófocles: Áyax, 1351 y 1371.

86 Esquilo: Agamenón, 681-685. Cf. Sófocles: Filoctetes, 1290.

87 Himno homérico a Apolo, 162-164. Véase Dumézil, G.: Apollon sonore. Esquisses de mythologie, Paris, 1982, pp. 31-33.

88 Homero: Odisea, XXI, 410-411.
} 
de la comunidad bajo la autoridad de los jefes del génos, de los kosmétores laôn ${ }^{89}$. Como puede apreciarse, el orden que se venera y actualiza mediante el culto tradicional es el del propio kósmos. Expresiones como «ou katà kósmon»o «ákosmos», poseedoras de una carga estético-moral terminante, hacen referencia a las acciones inadecuadas o impías que vulneran las disposiciones concretas y las prácticas impuestas por la costumbre. La norma se confunde con el rito religioso, con la distribución de sus distintas funciones ceremoniales, y bosqueja una jerarquía valorativa aceptada por el cuerpo social. Ese reconocimiento permanente coincide con la actividad de cantar y de reverenciar a los dioses (nomizein theoús). La akinesía de la arché se nutre de la multiplicidad de los nómoi, del combate sostenido de sus rumores. Sin esa polifonía, consustancial al pluralismo diegético que teje el imaginario griego ${ }^{90}$, no sería posible la intervención de los dioses. Su perdurabilidad reclama la asiduidad de la invocación, el halo de un poema o de un himno reinterpretado oralmente en una tradición viva de improvisación reglada.

Por lo tanto, puede afirmarse que la hierofanía del theîos nómos -básicamente sonora- se sostiene retroactivamente en la eufonía del nómos katà nómon, del canto correctamente construido que representa las demarcaciones del poder divino y la cartografía simbólica de la comunidad helena. Ese mapa sistemático elaborado por las narraciones míticas carece de coherencia interna; pero permite deslindar algunas de las regularidades, de los conflictos, de las ambigüedades y de las contradicciones que atraviesan su esfera social. En ese contexto, la enunciación del nómos cumple una función axial. Ya se trate del lote proporcionado a cada uno por Zeus, de la norma que metodiza esa distribución o del aire inspirado que narra las gestas de los héroes, el papel que desempeña la emisión de los dictámenes legales resulta prioritario a la hora de elucidar la genealogía de la comunicación escrita.

Para concluir, veamos algunos ejemplos que subrayan esta nuestra tesis. A todo lo largo del corpus griego, nos encontramos con sobrados usos de la forma verbal «némo» que expresan la acción de distribuir oralmente un contenido determinado. Esa difusión vocal -núcleo de las manifestaciones heurístico-imitativas que constituyen la comunicación poética- presenta el aspecto de una profusión reglamentada de sonidos capaz de transmitir la gloria de tiempos pasados y las preocupaciones inmediatas del tejido social. Incuestionablemente, se trata de la recitación de un canto solista con acompañamiento musical que representa ante su público con la mayor eficacia figurativa posible un modelo arquetípico de actitudes y de comportamientos individuales o colectivos. En esa estructura comunicativa, el entrelazamiento de la voz del aedo y del son de la lira provoca un rumor o un ruido (ktýpos)

89 Homero: Ilíada, I, 16. Cf. Benveniste, E.: Le vocabulaire des institutions indo-européennes, Paris, 1969, p. 103.

90 Buxton, R.: Imaginary Greece. The Contexts of Mythology, Cambridge, 1994, cap. I. Trad. cast.: El imaginario griego, Madrid, 2000, pp. 23-30. 
destinado a propalar la areté de los héroes que celebra el épos narrativo conforme a las leyes del canto (énnomos thalía). El fragmento de los Peanes de Píndaro que recoge esa concepción de la performance inspirada sostiene lo siguiente: «i(de liras) el brillo innumerable y de voces para difundir (némein) las infinitas hazañas de los Eácidas! [...] ¡Acoge, Peán, a quien se cuida con frecuencia de la flor de las Musas fieles a las normas de la fiesta» ${ }^{91}$. Como puede apreciarse, la composición del poeta -imbuida de sabiduría mántica- cumple el cometido de administrar oralmente la kléos de lo nombrado: la gloria que sobrevive, gracias a la declamación del lógos, al olvido de los hombres.

En las Euménides de Esquilo, nos encontramos con un contexto lingüístico muy similar. Al igual que sobreviene con la expresión formularia épica o lírica, la dicción adivinatoria de Apolo es objeto de un reparto semántico. El pasaje donde concurre esa idea dice así: «A pesar de que no te atañe, estás mostrando respeto con delitos de sangre -le reprocha el corifeo al dios-, así que, cuando pronuncies tus oráculos, ya no los podrás anunciar (némein) libres de mancha»92. De nuevo el verbo «némo» aparece asociado a la enunciación de la manteía, a la difusión de la palabra sagrada. La entonación oracular, del mismo modo que la asignación ritual de bienes homérica, constituye una distribución normalizada, un suministro sonoro. En realidad, esa concepción del discurso revelado nos permite atribuir al vocablo «nómos» el significado de «lectura», de «recitación reglada».

Los antecedentes de ese sentido olvidado pueden encontrarse en Homero y en Hesíodo. Para ello, basta con subsanar -como han hecho con acierto Jean Humbert y Jesper Svenbro93 - los errores de acentuación tradicionales que han transformado el nómos oidês homérico en un bucólico e incomprensible «pasto de palabras» (epéon nomós). La primera expresión forma parte del Himno homérico a Apolo y su interpretación resulta mucho más confusa e intrincada si nos decantamos por el campestre «nomós» que si resolvemos desplazar un ápice la tilde al objeto de darle un vuelco a las versiones menos sagaces y realzar ponderativamente la naturaleza distributiva del canto. A nuestro modesto entender, los versos pueden leerse como sigue: «Por ti, oh Febo, se ha derramado en todas partes una profusión de cantos, tanto en el continente, criador de terneras, como en las islas (pántei gár toi, Phoîbe, nómos bebléatai oidês, emèn an'épeiron portitróphon ed' anà nésous)»94. En la Ilíada, nos enfrentamos a una dificultad análoga. Nuevamente, la acentuación alternativa que hemos sugerido encaja con mayor holgura y satisfacción en un fragmen-

\footnotetext{
91 Píndaro, fr. 52 f, 175-183: «[...] i myría[n phl]óg’opôn te do- / kt]ýpoi n[ém]ein apeironas aretás / Aiak]idân. [...] Moisân / d'epaboléont [i] polláki, Paián, dé- / x'ennómon th [alí]an».

92 Esquilo: Euménides, 715-716: «all' aimaterà prágmat' ou lachòn sébeis, manteîa d'oukéth' agnà manteúsei némon».

93 Véanse Humbert, J. (ed.): Hymnes homériques, Paris, 1936 y Svenbro, J.: Phrasikleia. Anthropologie de la lecture en grèce ancienne, op. cit., pp. 126-128.

94 Himno homérico a Apolo, 20-21.
} 
to centrado en la dinámica de la glôssa humana y en los mýthoi que la recorren cargados de múltiples sentidos: «Versátil es la lengua de los mortales. Hay en ella discursos de toda índole y una copiosa efusión de palabras aquí y allá. Según hables, así oirás hablar de ti (streptè dè glôss' estì brotôn, polées d'éni mýthoi pantoîoi, epéon dè polýs nómos éntha kai éntha. Hoppoîón k' eipeistha épos, toîon k' epakoúsais. )» ${ }^{95}$. No se entiende cuál podría ser la pertinencia de la metáfora pastoral en este asunto; máxime, cuando lo que realmente está en juego en el párrafo es la distribución del habla, su diversidad y sus efectos. Lo mismo sucede una vez más en Los trabajos y los días. De una frase cuando menos oscura podemos obtener una sentencia llena de sentido con solo que restauremos su significación original. Para tal menester, como en el lance previo, basta con reintroducir la voz «nómos» en su lugar correspondiente: «[...] dirás muchas cosas vanas, y la emisión de palabras será inútil (sý d'etósia póll'agoreúeis, achreîos d'éstai epéon nómos)»96.

Esa distribución oral (nómos) cobrará con el tiempo el significado de «lectura». Al respecto, resulta especialmente significativo el fragmento 144 de Sófocles: «Tú, que en tu trono tienes las tablillas de lo escrito, lee (néme) si no asiste alguno que se hubiera unido al juramento» ${ }^{97}$. [... $]^{98}$.

\section{VII}

Como hemos visto, y a modo de conclusión, en el marco de su origen oral, al cabo la ley se presenta como una «exégesis», su fuerza es la de la diseminación simbólica de lo preferible -mudable, temporal y contingente-, aunque en el marco de la teonomía, antes de la irrupción de cualquier posible hermenéutica jurídica, su promulgación sólo entrañe la hierofanía de la ley eterna, de la aristeía de la arché.

La práctica de la antigua thémis era inseparable de su contexto oral de efectuación. Su carácter imperativo venía unido a la singularidad de una voz soberana, singular e intrasferible, capaz de atesorar el poder supremo que juzgaba y decidía el decurso comunitario. La elocución de sus órdenes, mandatos o decretos (thémistes) poseía una autoridad suprema. Tanto el ánax como el basileús arcaicos, al igual que el Cronos de Las leyes de Platón con el que comenzamos, regían de forma paternofilial a una multitud (laós) indiferenciada, a una masa de población, los polloí, unificada en torno a una sola voluntad y, también en ocasiones, gracias a la gloria can-

95 Homero: Ilíada, XX, 248-250.

96 Hesíodo: Los trabajos y los días, 402-403.

97 Sófocles, fr. 144. Sobre la relación entre «nómos», «exégesis» y «lectura», puede verse el gran número de referencias aportado por Jesper Svenbro en Phrasikleia, op. cit., pp. 123-136.

98 Por razones de extensión, se interrumpe aquí de forma algo abrupta el desarrollo de la exposición. Lo que resta del artículo se publicará en otra ocasión. No obstante, de cara a la comprensión del mismo y de los objetivos de la investigación, resumimos en lo que sigue algunas de las conclusiones principales. 
tada (kléos) de los héroes, de los verdaderos áristoi. Sería otra aristocracia la que heredaría, siglos después, ya en tiempos de Sócrates, ese sentido gentilicio del derecho divino de los reyes arcaicos, esa actitud reverencial ante las leyes del señor de huestes, que impone derechos y otorga deberes al amparo del origen divino de su majestad ${ }^{99}$; pero antes habría de llegar todo un proceso de transferencia de la potestas que habría de comenzar con las magistraturas del árchon y del polémarchos, con capacidad de decisión en los asuntos familiares y de propiedad, y en los militares, respectivamente. Después de ellos, sería el turno de los jueces dadores de leyes, del tribunal del Areópago y, finalmente, como es sabido, de la institución de la ekklesía, de la asamblea ciudadana soberana en materias de política exterior e interior ${ }^{100}$. Ese traspaso sería lento, y es posible incluso que no haya finalizado todavía, que la organización legal arcaica siga estando más vigente de lo que pensamos en muchos contextos prepolíticos contemporáneos (de ahí nuestra inclinación presente hacia la antigua Grecia); pero al menos dejaría atrás las formas más radicales de ordenamiento religioso de la acción colectiva, de «teonomía», esto es, de disposición o establecimiento sacral que prescribe, instituye y erige el deber ser inquebrantable de los llamados a caer bajo un mismo génos.

Sin embargo, como hemos subrayado con anterioridad, ese vuelco de las relaciones de poder no se daría sin violentar las lindes de la religiosidad precedente (reinversión de la bía divina de los siglos VII y VI), ni sin un olvido activo tanto del marco conceptual anterior (sustitución de la noción de thémis por la de nómos), como del modo en que la antigua voluntad despótica del tirano o de los dioses se reintroducía ahora en el texto de la ley compartida, en la fuerza de un reparto regulado que también restringía el ejercicio de la libertad ciudadana. Como subraya Demarato al propio Jerjes en la Historia de Heródoto, los griegos «pese a ser libres, no son libres del todo, ya que rige sus destinos un supremo dueño (despótes), la ley (nómos), a la que, en su fuero interno, temen mucho más, incluso, de lo que tus súbditos te temen a ti» 101 . Como tantas veces sucede, la inversión de papeles que supuso el reemplazo del derecho divino por la ley humana no conllevó cambio estructural alguno: el nómos cumplía idéntica función al tirano preexistente; sólo que ahora lo hacía de forma larvada, anclado en el pecho de los frágiles mortales.

\footnotetext{
99 Benveniste, E.: Le vocabulaire des institutions indo-européennes, París, 1969, vol. II, p. 103: «En la epopeya, se entiende por thémis la prescripción que fija los derechos y los deberes de cada uno bajo la autoridad del jefe del génos tanto en la vida cotidiana en el interior de la casa, como en circunstancias excepcionales: alianza, matrimonio y combate».

$100 \mathrm{Al}$ respecto, siguen resultando del mayor interés las tesis de Ostwald, M.: Nomos and the Beginnings of the Athenian Democracy, Oxford, 1969 y MacDowell, D. M.: The Law in Classical Athens, Ítaca, Cornell University Press, 1978. Cf. Mas Torres, S.: Ethos y pólis. Una historia de la filosofia práctica en la Grecia clásica, Madrid, Ítsmo, 2003, pp. 13-18.

101 Heródoto: Historia, VII, 104.
} 
A su vez, el pavor que ejerció en las conciencias el nuevo código, este nuevo régulo de la «compartición» colectiva se sirvió de la potencia de una nueva téchne, la escritura, para publicar, difundir y comunicar los mandatos de la pólis, convertida ahora no sólo en agente legislativo, sino en autócrata figuradamente absoluto. La graphé del dêmos semiotizó la arché arcaica y la sustituyó por la reiteración de sus signos, por el fetiche iterable de las letras 102 , capaz de fijar, de indicar el sentido de la prâxis pública y de inscribirse aún más hondo en su memoria, denunciando toda acción contraria a la pauta sancionada positivamente por la comunidad política.

Si bien es cierto que el nómos despotés, garante de la nueva isonomía 103 , logró arrumbar así el falso brillo de las figuras de derecho precedentes, apoyándose en su propia hýbris impía, en la temible fuerza de su ley escrita, no lo es menos que ese miedo, a nuestro juicio, y a despecho de Eurípides, hizo de la ciudad una tirana para sí misma. Y pocas cosas impiden más el ejercicio de la justicia que la prescripción pretendidamente perenne de tò koinón, que su determinación imperativa e identitaria, esto es, timorata en el fondo, medrosa respecto a lo extraño, pues lo común, su entramado efectivo, no admite otro sobresalto, otro sobrecogimiento que la pasión de la libertad.

\section{Gabriel Aranzueque}

Departamento de Filosofía

Universidad Autónoma de Madrid

gabriel.aranzueque@uam.es

\footnotetext{
102 Retomamos aquí el final de nuestro trabajo «Políticas de la revelación. Lógos y prâxis en la tradición oracular griega», en Pensamiento, art. cit., pp. 413-440.

103 Eurípides: Las suplicantes, 429 y ss.: «Nada para la ciudad es más peligroso que un tirano. Primeramente, con él las leyes no son comunes para todos, gobierna un solo hombre que detenta la ley en sus propias manos, y ya no hay igualdad. Por el contrario, cuando las leyes están escritas, el débil y el rico gozan de igual derecho». Sobre la relación entre el nómos týrannos y la escritura, puede verse con provecho el excelente trabajo de Patxi Lanceros «Justicia. Una (leve) historia conceptual en perspectiva política», en Oncina, F. (ed.): Teorías y prácticas de la historia conceptual, Madrid, CSICPlaza y Valdés, 2009, pp. 137-160.
} 